\title{
CORRECTION
}

\section{Correction to: Sagittal balance of the spine}

\author{
J. C. Le Huec ${ }^{1} \cdot$ W. Thompson ${ }^{1} \cdot$ Y. Mohsinaly ${ }^{1} \cdot$ C. Barrey $^{1} \cdot$ A. Faundez ${ }^{1}$
}

Published online: 26 August 2019

(c) Springer-Verlag GmbH Germany, part of Springer Nature 2019

\section{Correction to: European Spine Journal}

https://doi.org/10.1007/s00586-019-06083-1

The original publication of the review article by Le Huec JC, Thompson W, Mohsinaly Y, Barrey C, Faundez A, entitled "Sagittal balance of the spine" (Eur Spine J, 2019: DOI 10.1007/s00586-019-06083-1) contained an error. The figure 20 is not from the study by Shiba et al., but is a courtesy from Dr Stéphane Armand, Laboratory of Kinesiology, Geneva University Hospitals, Geneva/Switzerland.

Publisher's Note Springer Nature remains neutral with regard to jurisdictional claims in published maps and institutional affiliations.

The original article can be found online at https://doi.org/10.1007/ s00586-019-06083-1.

J. C. Le Huec

jclehuec1@gmail.com

1 Spine Unit, Polyclinique Bordeaux Nord Aquitaine, Université Bordeaux, 33000 Bordeaux, France 